\title{
Morphology, anatomy and ultrastructure of the leaf blade in Froelichia tomentosa (Mart.) Moq. (Amaranthaceae A. Juss): - a critically endangered species in Brazil
}

\author{
Morfologia, anatomia e ultraestrutura foliar de Froelichia tomentosa \\ (Mart.) Moq. (Amaranthaceae) - uma espécie criticamente ameaçada \\ de extinção no Brasil
}

\author{
Aline Viana' $^{10}$, Elisete Maria de Freitas ${ }^{\prime \prime}(\mathbb{D})$, Shirley Martins ${ }^{1}(\mathbb{D}$ \\ 'Universidade Estadual do Oeste do Paraná, Cascavel, PR, Brazil \\ "Universidade do Vale do Taquari, Lajeado, RS, Brazil
}

\begin{abstract}
In Brazil, Froelichia tomentosa (Mart.) Moq. has records of occurrence in Rio Grande do Sul (RS) and Bahia, however, in the former there are indications that its populations are extinct. In the RS, the records are restricted to the region of sandy- fields. In this region, biodiversity has been threatened by advances in agriculture and forestry that intensified in the sandy patch process. Therefore, this work aimed to describe the morphoanatomy and ultrastructure of the leaf blade in Froelichia tomentosa, seeking to correlate leaf characteristics to the environmental conditions. Individuals from different populations in the sand- fields (Pampa biome) were sampled. Leaf blade analyzes were performed by scanning electron microscopy (SEM), transmission electron microscopy (MET) and optical microscopy (MO). The following anatomical features were verified: epidermis with trichomes and stomata in the adaxial and abaxial surface, compact mesophyll, aquiferous hypodermis, Kranz anatomy, and numerous plastoglobules and peroxisomes. The presence of these characters may be related to the adaptation of this species to environment. In addition, we highlight the necessity to create conservation units in the sand-fields region, in order to preserve species as well as that of the present study.
\end{abstract}

Keywords: Amaranthaceae; Anatomy Kranz; Sandy-fields; Chloroplasts; Threatened species; Adaptive strategies 


\section{RESUMO}

No Brasil, Froelichia tomentosa (Mart.) Moq. possui registros de ocorrência no Rio Grande do Sul (RS) e na Bahia, no entanto, no primeiro há indícios de que suas populações estão extintas. No RS, os registros são restritos à região dos campos arenosos. Nessa região vem sofrendo redução da biodiversidade, devido à intensificação do processo de arenização. Portanto, este trabalho teve como objetivo descrever a morfoanatomia e a ultraestrutura da lâmina foliar de Froelichia tomentosa, buscando correlacionar as características foliares às condições ambientais. Foram amostrados indivíduos de diferentes populações nos campos de areia (bioma Pampa), as análises da lâmina foliar foram realizadas em microscópio eletrônico de varredura (MEV), microscopia eletrônica de transmissão (MET) e microscopia óptica (MO). Verificou-se as seguintes características anatômicas: epiderme com tricomas e estômatos na superfície adaxial e abaxial, mesofilo compacto, hipoderme aquífero, anatomia de Kranz e numerosos plastoglóbulos e peroxissomos. A presença desses caracteres pode estar relacionada à adaptação dessa espécie ao ambiente. Além disso, destacamos a necessidade de criação de unidades de conservação na região de areia, a fim de preservar espécies, bem como a do presente estudo.

Palavras-chave: Amaranthaceae; Anatomia Kranz; Campos arenosos; Cloroplastos; Espécie ameaçada; Estratégias adaptativas

\section{INTRODUCTION}

Froelichia tomentosa (Mart.) Moq. belongs to the Amaranthaceae and has a Neotropical distribution with predominant occurrence in savannah environments (MARCHIORETTO et al., 2004). In Brazil, this species has records of occurrence for the Northeast (Bahia state, Caatinga biome) and South (Rio Grande do Sul state, Pampa biome); however, there are indications that the population in the Northeast is extinct, due to the collections in this region dating from 1815-1817 by the naturalist Friedrich Sellow (MARCHIORETTO et al., 2004; MARCHIORETTO et al., 2005). In Rio Grande do Sul (RS), populations of F. tomentosa have records restricted to the phytophysiognomy of sand- fields, occupying the Pampa biome (MARCHIORETTO et al., 2004; FANK-DE-CARVALHO et al., 2012).

The sand-fields present environmental conditions considered to be harsh for many plants, such as high temperatures and insolation, water deficit, intense cold and strong winds (OLIVEIRA \& SUERTEGARAY, 2014). In addition, they are susceptible to the sandy patch process (FREITAS et al., 2009; SCOPEL et al., 2013), resulting from the humid climate and wind action that rework the sandstone, depositing sand on the surface and promoting constant sediment mobility (SUERTEGARAY \& BERTE, 
1997; SUERTEGARAY et al., 2001; OLIVEIRA \& SUERTEGARAY, 2014). Together with this process, overgrazing and increased agriculture and forestry in the region are environmental problems that lead to the reduction of biological diversity (MMA, 2007; OVERBECK et al., 2009; PILLAR \& LANGE, 2015).

The conversion of native ecosystems to cultivated areas may lead the reduction of populations of native species, and also the extinction of species, depending on their distribution range (METZGER et al., 2019; PILLAR \& LANGE, 2015). Furthermore, the current distribution of the species reflects the environmental conditions experienced throughout their evolutionary history, being in accordance with the physical and biological conditions adequate for their survival and reproduction (DASILVA, 2011). Thus, a species restricted to specific areas has particularities in its structure and physiology to survive the environmental changes.

Currently, 2953 species of plants in Brazil are included in the list of endangered species (CNCFlora, 2017) and, for the preservation of these species, it is necessary to be aware of their state of conservation and distribution. In addition, areas of great interest for conservation present patterns of endemism and the occurrence of endangered species (GIULIETTI et al., 2005; MARCHIORETTO et al., 2005). In this context, it is noteworthy that the conservation of Froelichia tomentosa in the Pampa necessary, since agriculture and forestry have been increasing in large areas of the region in the last few years, besides the intensification of the sandy patch process (FREITAS et al., 2010), mainly because this species is classified as critically endangered (SEMA, 2013).

Studies involving the studied species have focused on taxonomy (SAGE et al., 2007), floristic surveys (FREITAS et al., 2009, 2010; FANK-DE-CARVALHO et al., 2012; MARCHIORETTO, 2013), distribution pattern (MARCHIORETTO et al., 2004), and biogeography (MARCHIORETTO et al., 2008). On the other hand, data on the anatomical structure, ultrastructure and physiology of the species were not found in the literature. 
Leaf anatomy has been shown to be promising in the ecological field, since these organs reflect the environmental conditions of the habitat in which the plants live (SOMAVILLA \& RIBEIRO, 2011; FANK-DE-CARVALHO et al., 2010b; SIMIONI et al., 2017). Given the importance of the critical conservation status of Froelichia tomentosa, the objective of this study was to describe the morphology, micromorphology, anatomy and ultrastructure of the blade leaf in order to identify environmental adaptations, and increase knowledge about this species for conservation of the Pampa areas.

\section{MATERIALS AND METHODS}

Individuals of Froelichia tomentosa were collected in May, October and December 2016 and April 2017 (at least three individuals in each field trip, 4-5 leaves from each individual), on private properties with native vegetation classified as sandy-fields, inserted in the Pampa biome. Collections were made in the municipalities of Manoel Viana and São Francisco de Assis, in southwestern RS, Brazil, between latitudes $29^{\circ} 00^{\prime} \mathrm{S}$ and $31^{\circ} 00^{\prime} \mathrm{S}$ and longitudes $54^{\circ} 30^{\prime} \mathrm{W}$ and $58^{\circ} 45^{\prime} \mathrm{W}$. According to the Köppen classification system, the climate of the region is of type Cfa, mean annual rainfall is between 1,299 and 1,500 mm, with random precipitation. The mean seasonal temperature is $14^{\circ} \mathrm{C}$ in winter and $26^{\circ} \mathrm{C}$ in summer (NIMER, 1979). The soil is classified as Orthic Quartzarenic Neosol, with sandy granulation and sandy silt, with high concentrations of metals (STRECK et al., 2008).

Specimens of F. tomentosa (A. Viana et al., 24; E. Freitas 1050) were herborized and deposited in the UNOP Herbarium of the State University of the West of Paraná, Cascavel campus, for morphological description. Five other individuals were processed for light and electron microscopy analysis.

Light Microscopy (LM) - For the light microscopy (LM) analysis, leaves were fixed in 50 FAA (JOHANSEN, 1940) and preserved in 70\% ethyl alcohol. In order to 
observe the leaf blade in frontal view, leaf fragments of the median region, approximately $1 \mathrm{~cm}^{2}$, were submerged in acetic acid and hydrogen peroxide 1:1 (FRANKLIN, 1945; modified) for 24 hours in an oven at $50^{\circ} \mathrm{C}$, washed in distilled water, stained with 50\% safranin (KRAUS \& ARDUIN, 1997) and mounted on semipermanent slides in 50\% glycerin.

For the anatomical analysis of leaf blade in transverse section, samples from the median region of fully expanded leaf blades were sectioned by hand with a razor blade, clarified with $80 \%$ sodium hypochlorite, stained with Alcian Blue and Basic Fuchsin and mounted in 50\% glycerin (PURVIS et al., 1964). The sections were also submitted to microchemical tests with Lugol (BERLYN \& MIKSCHE, 1976) for identification of starch; ferric chloride (Johansen 1940) for phenolic substances, Sudan IV (SASS, 1951) for lipids and methylene blue (JOHANSEN, 1940) for mucilage. The results were documented using a DP041 digital camera coupled to an Olympus Bx70 photomicroscope using the program DP Controller.

Scanning Electron Microscopy (SEM) - For the SEM analysis, samples from the median region of fully expanded leaf blades were fixed in $2.5 \%$ glutaraldehyde solution in $0.1 \mathrm{M}$ phosphate buffer, $\mathrm{pH} 7.3$, dehydrated in an increasing alcohol series and metalized with gold powder. This analysis was performed at the Laboratory of Scanning Electron Microscopy of the Science and Technology Park (Tecnovates), of the "Universidade do Vale do Taquari - Univates" (Lajeado, RS).

Transmission Electron Microscopy (TEM) - For the ultrastructural analysis in TEM, samples from the median region of fully expanded leaf blades were fixed in $2.5 \%$ glutaraldehyde solution in $0.1 \mathrm{M}$ phosphate buffer, $\mathrm{pH} 7.3$, post-fixed in $0.5 \%$ osmium tetroxide, washed in distilled water, dehydrated in increasing series of acetone solutions, soaked, and included in Araldite. The ultrathin sections were obtained with the aid of a microtome, approximately $90 \mathrm{~nm}$ wide, and were contrasted with lead citrate and ethyl uranyl acetate. Visualization was analyzed with a Tecnai Spirit Transmission Electron Microscope - FEl Company. These 
analyses were performed at the Electronic Microscopy Center of the "Universidade Estadual Paulista" (Botucatu campus, SP).

\section{RESULTS}

Froelichia tomentosa is a perennial herb, $30-80 \mathrm{~cm}$ high; principal root woody and superficial; leaf opposite, simple, petiolate, elliptical or obovate, 2.4-8.4 × 1.0$3.5 \mathrm{~cm}$, apices and bases acute, thickened at the base, smooth margins, membranaceous, tomentose (Fig. 1A-C); inflorescence (Fig. 1D) spicate; small yellow flowers, sepals connate to near the apex.

Figure 1 - Froelichia tomentosa (Mart.) Moq. A. Overview of morphology. B. Overview of the leaves. C. Leaf detail. D. Inflorescence detail

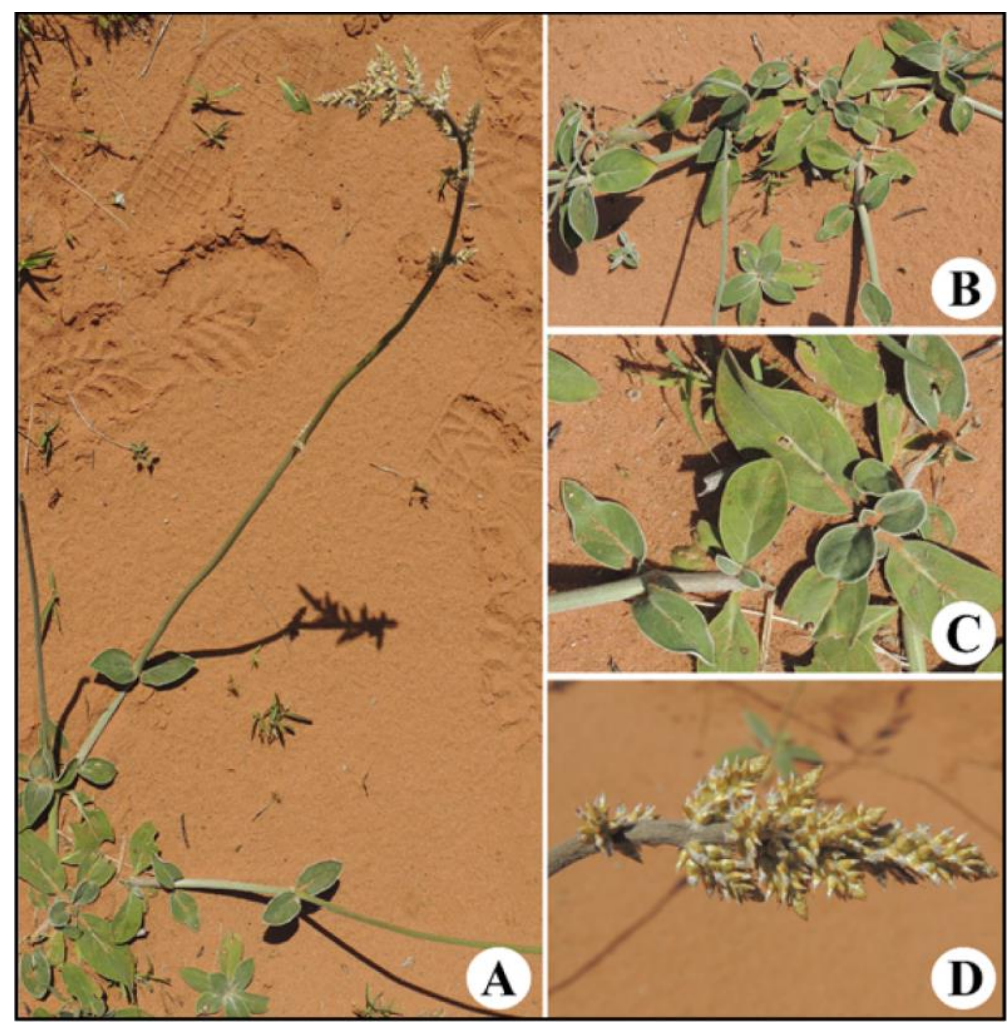

Individuals from sandy-fields of different populations, are similar in their morphological structures. Scanning electron microscopy (SEM) observations have shown that the leaves are characterized by multicellular, unistratified, and long non-glandular trichomes (Fig. 2A-B). Under light microscopy (LM), the trichomes 
present basal cells broader and shorter, whereas the apical cells are narrower and longer (Fig. 2C, F). Stomata occur on both leaf surfaces, especially among trichomes (Fig. 2E, F).

Figure 2 - Froelichia tomentosa leaf blade in frontal view of the epidermis in SEM and LM. A-B. Leaf blade in frontal view in SEM. A. Adaxial surface. B. Trichomes, abaxial surface. C-K. Leaf blade in transverse section in LM. C. Mesophyll Overview. D. Mesophyll with druses. E. Epidermis showing stomata and thickening of the external periclinal wall. F. Detail of the epidermis with trichomes. G. Mesophyll, highlighting abaxial hypodermis. H. Mesophyll detail showing vascular bundle and chlorophyll sheath. I. Midrib (MR) Overview. J. Detail of MR epidermal cells. K. Detail of the MR vascular bundles

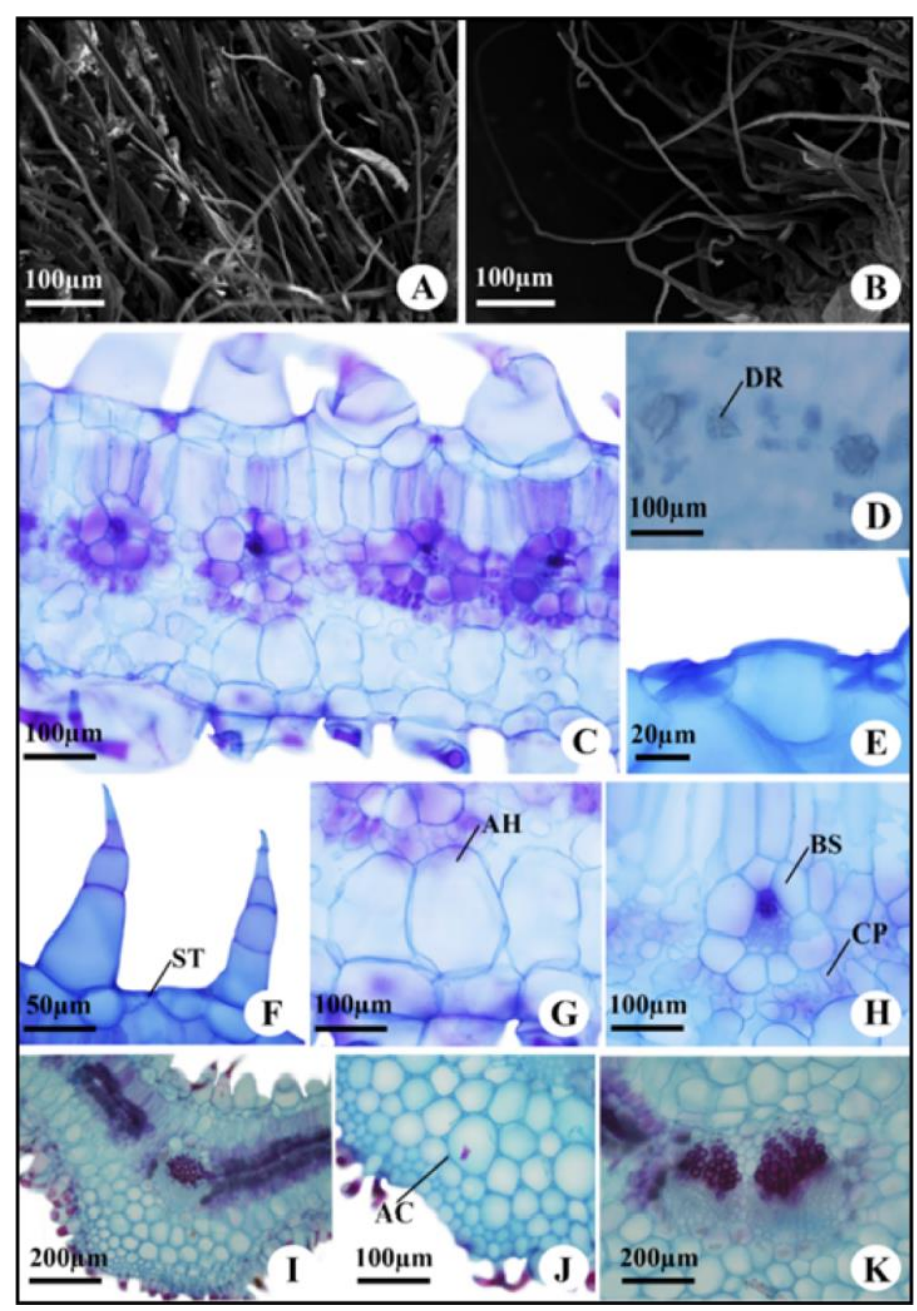

$\mathbf{A C}=$ Angular collenchyma; $\mathbf{A H}=$ aquiferous hypodermis; $\mathbf{B S}=$ Vascular bundle sheath; $\mathbf{C P}=$ Chlorophyllous parenchyma; $\mathbf{D R}=$ Druse; $\mathbf{S T}=$ Stomata 
It was not possible to describe the characteristics of epidermal cell walls due to the large number of trichomes. The leaf blade in transverse section shows an unistratified epidermis (Fig. 2C) covered by a thin and smooth cuticle (Fig. 2E). The epidermical cells are with rectangular, proportional in size between the adaxial and abaxial surfaces, with slightly thickened, external periclinal cell walls (Fig. 2C, E). Stomata occur at the same level as the other epidermal cells and guard cells have slightly thickened walls (Fig. 2C, E).

The mesophyll presents an adaxial hypodermis composed by water-storage parenchyma (Fig. 2G). The mesophyll region thickness measured $221.54 \pm 18.04 \mu \mathrm{m}$ and is dorsiventral with unistratified palisade parenchyma and uni-bistratified spongy parenchyma (Fig. 2C).

Near the vascular bundles, the cells of the chlorophyllous parenchyma are radially, arranged around the vascular bundle sheaths (Fig. 2C, H). The vascular bundle sheath presents thin-walled cells with large chloroplasts (Fig. $2 \mathrm{H}$ ). The vascular bundles are collateral (Fig. 2C, H). Some chlorophyllous parenchyma cells had druses, mainly among vascular bundles (Fig. 2D)

In the region of the midrib, the epidermal cells of both surfaces are smaller than those located in the mesophyll region (Fig. 2J). Internally to the epidermis there are 3-4 layers of angular parenchyma (Fig. 2J), followed by cortical parenchyma with bulky and rounded cells (Fig. 2J) and one to two collateral vascular bundles, without the presence of fibrous caps (Fig. 2l, K).

In the ultrastructural analysis of photosynthetic tissues of the leaf blade, the presence of dimorphic chloroplasts can be observed between the cells of the chlorophyllous parenchyma and the cells of the vascular bundle sheath (Fig. 3A). In the cells of the chlorophyllous parenchyma, the chloroplasts are peripherally located, have a lenticular shape and thylakoids form grana (Fig. 3B). Plastoglobules and oil droplets occur in large quantities inside these chloroplasts (Fig. 3B). 
Figure 3 - Transverse section of the leaf blade of Froelichia tomentosa under TEM. A. Photosynthetic tissues. B. Cloroplasts with grana in the cells of the chlorophyllous parenchyma. C. Cells of the vascular bundle sheath showing the plasmodesmata. D. Vascular bundle sheath cell. E. Plasmodesmata between the cells of the vascular bundle sheath and the chlorophyllous parenchyma. F-H. Chloroplasts in the vascular bundle sheath. F. Plastoglobules and oil droplets. G. Parallel thylakoids, starch grains, plastoglobules and oil droplets. H. Peroxisomes. I. Mitochondria

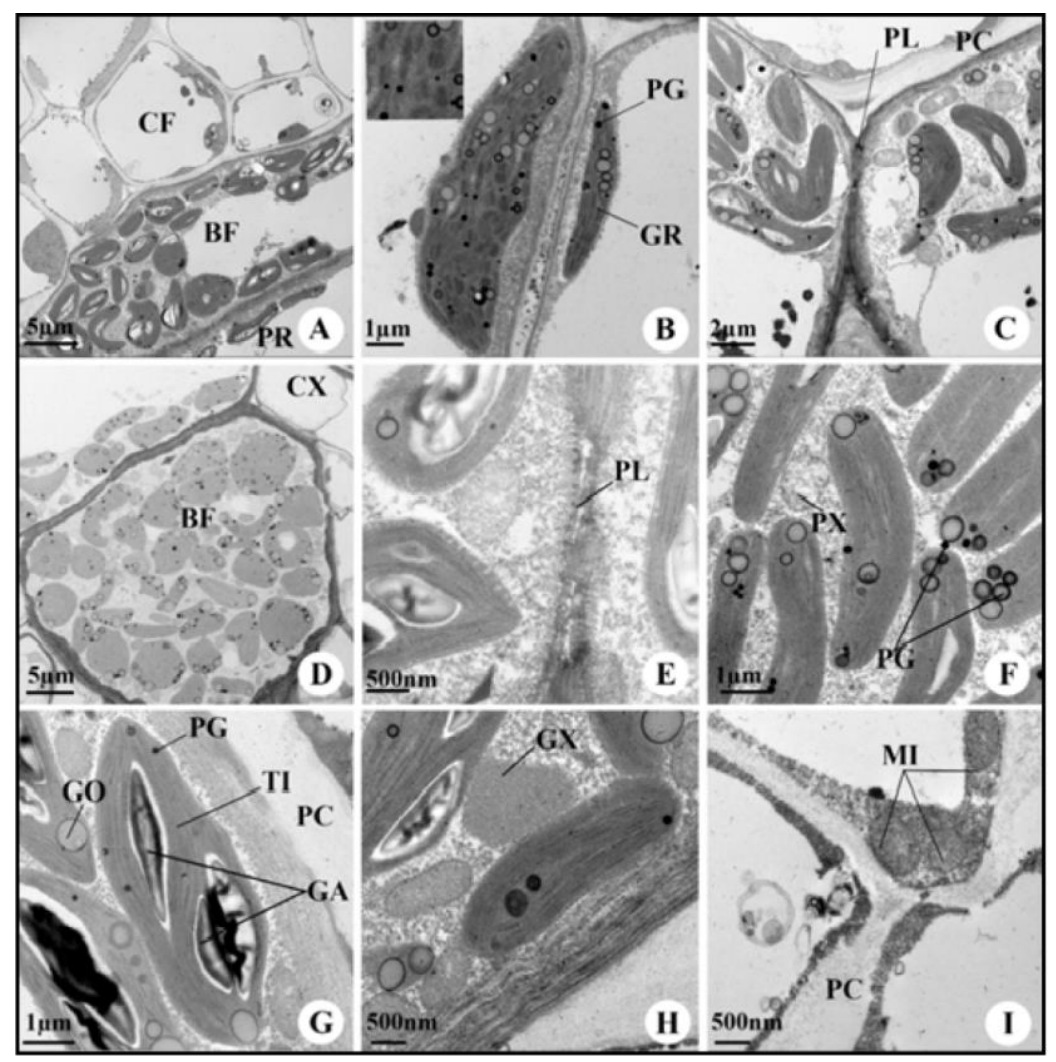

BC = Vascular bundle cell; $\mathbf{B S}=$ Vascular bundle sheath; $\mathbf{C P}=$ chlorophyllous parenchyma; $\mathbf{C W}=$ Cell wall; $\mathbf{G R}=$ Grana; $\mathbf{M I}=$ Mitochondria; $\mathbf{O D}=$ Oil droplets; $\mathbf{P G}=$ Plastoglobules; $\mathbf{P L}=$ Plasmodesmata; $\mathbf{P X}=$ Peroxisome; $\mathbf{S G}=$ Starch grain; $\mathbf{T L}=$ Thylakoids

In the vascular sheath cells, chloroplasts are found distributed throughout the cell in various shapes, from lenticular to rounded (Fig. 3A, C-D), and have parallel thylakoids (Fig. 3F). Inside the chloroplasts, the presence of large starch grains, plastoglobules and oil droplets can be observed (Fig. 3F-G). Plasmodesmata are observed between the cells of the chlorophyllous parenchyma and the cells of the 
vascular bundle sheath (Fig. 3E) and also between adjacent cells of this sheath (Fig. 3C). In the phloem cells, chloroplasts are also observed (Fig. 3A).

Mitochondria occur in both photosynthetic tissues (chlorophyllous parenchyma and vascular bundle sheath), but are more abundant in cells of the bundle sheath, usually located near the chloroplasts (Fig. $3 \mathrm{H}-\mathrm{I}$ ). Peroxisomes are also observed, mainly in the cells of the bundle sheath and in high quantity (Fig. 3E, $F, H)$.

\section{DISCUSSION}

The following characteristics of the leaf blade of Froelichia tomentosa are shared with other species of the family Amaranthaceae [Pfaffia gnaphalioides (L.f.) Mart., Froelichiella grisea (Lopr.) R.E. Fr. and Gomphrena hermogenesii J. C. Siqueira]: opposite phyllotaxy, petiolate, membranaceous, entire margin, and acute apex (Fank-de-Carvalho et al., 2010a). The morphological similarity among these species becomes difficult their identification. Despite that, Siqueira (2002) and Fank-deCarvalho et al. (2010a) highlighted the taxonomic value of floral characters.

Unlike most species of Amaranthaceae with semi-woody roots or xylopodium, F. tomentosa has a principal root woody. The occurrence of well-developed subterranean system is fundamental for the rehabilitation of species and, favors the pioneer establishment in more distant areas. So, the absence of a developed subterranean system in the $F$. tomentosa can restrict the distribution or hinder survival in fire or pasture situations (FANK-DE-CARVALHO, MARCHIORETTO \& BÁO, 2010a).

Besides to the genetically determined characteristics common to the family, many species of Amaranthaceae present anatomical and ultrastructural variations, possibly related to their environments of origin and occurrence, reflecting different survival strategies (FANK-DE-CARVALHO \& BÁO, 2011). In the leaf blade of $F$. tomentosa studied here, we suggest some adaptive strategies: associated with 
water stress, high solar radiation and soil mobility, such as abundance of trichomes, stomata on both leaf surfaces, aquiferous hypodermis, druses, compact mesophyll and Kranz anatomy, as presented below.

Trichomes distributed across all leaf surfaces, especially long ones as observed in F. tomentosa, allowing the maintenance of an atmosphere saturated with water vapor around the stomata (ELIAS et al., 2003), thus reducing water loss through transpiration. Trichomes reduce the absorption of solar radiation, regulating the internal temperature of the leaf and avoiding damage to the photosynthetic apparatus (ELIAS et al., 2003; ARRUDA et al., 2009; FANK-DECARVALHO et al., 2010b; FANK-DE-CARVALHO et al., 2012). Dense trichome cover can also act as protection against pathogens and herbivores (JOHNSON, 1975).

The occurrence of stomata on both leaf surfaces, is considered a common feature in plants of xeric environments, and can be interpreted as a strategy to optimize the photosynthetic capacity of the plants while avoiding excessive water loss. This is possible due to the ability to reduce the time in which the stomata remain open (MOTT et al., 1982; FAHN \& CUTLER, 1992; FANK-DE-CARVALHO et al., 2015).

In xeric environments, in addition to the strategies to reduce water loss, it is important to store water in water-storage tissues. Thus the presence of aquiferous hypodermis in $F$. tomentosa allows the maintenance of water levels to guarantee cell integrity, in addition to acting as a thermal insulation against the effects of excessive solar radiation, and controlling the excessive heating of the leaf (FAHN \& CUTLER, 1992; SILVA \& MEDEIROS, 2005; JÁUREGUI et al., 2014).

Another aspect observed in the species herein studied that assists in the maintenance of tissue and cell integrity is the compact mesophyll arrangement, since it provides greater structural rigidity, resistance to ruptures and possible membrane collapses due to water deficits (CUTLER et al., 2011).

Additionally, the radial arrangement of the chlorophyllous parenchyma cells around a single vascular sheath, with large chloroplasts, characterizes the 
occurrence of Kranz anatomy of the atriplicoid-type in Amaranthaceae species, as also described here for $F$. tomentosa. In this species, the occurrence of $\mathrm{C}_{4}$ photosynthetic metabolism had already been indicated on the basis of biochemical and carbon-marking data (MUHAIDAT et al., 2007).

The occurrence of small and dimorphic chloroplasts within the photosynthetic tissues, in addition to the dispersed location throughout the vascular bundle sheath cell with undeveloped grana and many mitochondria, as observed in the studied species, is characteristic of the biochemical subtype NADPME (malic enzyme pathway) (VOZNESENSKAYA et al., 1999; MUHAIDAT et al., 2007). Plants with $\mathrm{C}_{4}$-photosynthetic metabolism are generally associated with habitats under harsh environmental conditions, and may be tolerant to drought, high temperatures, high solar radiation and salinity (GRIGORE \& TOMA, 2007; MARTINS et al., 2008). Therefore, it is an important feature for the survival of $F$. tomentosa in open savanna areas, where this species is generally found (MARCHIORETTO et al., 2004).

In addition, some ultrastructural features of chloroplasts and other organelles may reflect high solar radiation condition (FERNANDES et al., 2014). As for chloroplasts, the presence of large and bulky starch grains in the bundle sheath cells, as in F. tomentosa, may be associated with more intense photosynthesis in these chloroplasts, in which both $\mathrm{CO}_{2}$ and the enzyme Rubisco are concentrated (GARNER et al., 2016).

The presence of many plastoglobules, as observed in the chloroplasts of the vascular bundle sheath in F. tomentosa, can be associated to the oxidative stress conditions of the photosynthetic apparatus that can be generated by the high insolation of the plant (AUSTIN et al., 2006). Plastoglobules are characterized by the presence of lipoprotein subcompartments that attach to the thylakoid membrane, biosynthetic enzymes, and photosynthetic proteins. The enzymes protect the thylakoid membrane while the proteins safeguard against damage from oxidative stress, as well as act as a defense against fungal infection (AUSTIN et al., 2006). 
Peroxisomes are also organelles associated to high solar incidence, in addition to water stress, since in these organelles there are storage enzymes connected to the combat of reactive oxygen species (ROS), mainly catalase (PALMA et al., 2009). Therefore, the presence of peroxisomes in large numbers, as observed in the cells of the vascular bundle sheath in $F$. tomentosa, suggest that these organelles perform intense activity in the reduction of ROS. The quantification of these organelles in other species of Pampa would be interesting as a possible stress marker for plants in this region.

Druses are common in representatives of the Amaranthaceae according to Metcalfe \& Chalk (1950). In F. tomentosa, druses were observed in the mesophyll, as well as the species included in the subfamily Gomphrenoideae studied by Fankde- Carvalho et al. (2012) and Playuk (2016). The presence of this structure can be related to the great concentration of minerals in the soil of the sand-fields (STRECK et al., 2008), which favors the formation of calcium oxalate crystals, with crystallization being a plant mechanism for the concentration and neutralization of excess calcium present in the cells interior and defense against severe environmental conditions (FRANCESCHI \& HORNER, 1980; PLAYUK, 2016).

In the present study of Froelichia tomentosa, a species threatened with extinction in Brazil, it was possible to identify some characteristics associated to the environmental conditions of the region, thus created adaptive strategies. Among these, we highlight trichomes covering the entire leaf surface, stomata on the adaxial and abaxial surface, compact mesophyll, aquiferous hypodermis, Kranz anatomy, many plastoglobules and peroxisomes. In this context, the importance of the creation of conservation units in the area of sand-fields is emphasized, aiming at the preservation of $F$. tomentosa and other native species. 


\section{ACKNOWLEDGMENTS}

We acknowledge the technical team of the Laboratory of Scanning Electron Microscopy of the Science and Technology Park - Tecnovates of Univates, and the Center of Microscopy of Unesp / Botucatu for providing the equipment and technical support for analysis involving electron microscopy. We also thank the "Coordenação de Aperfeiçoamento de Pessoal de Nível Superior" (CAPES) for the scholarship granted to the first author and the Araucária Foundation (51223/2017) for the financial support of the research.

\section{REFERENCES}

ARRUDA RCO, VIGLIO NSF, BARROS AAM. Leaf anatomy of halophytes and psammophilous plants from the Restinga of Ipitangas, Saquarema, Rio de Janeiro, Brazil. Rodriguésia [online]. 2009; 60(2): 333-352.

AUSTIN, JR, FROST E, VIDI PA, KESSLER F, STAEHELIN LA. Plastoglobules are lipoprotein subcompartments of the chloroplast that are permanently coupled to thylakoid membranes and contain biosynthetic enzymes. The Plant Cell. 2006; 18(7): 1693-1703.

BERLYN G, MIKSCHE J. Botanical microtechnique and cytochemistry. Ames, The lowa State University Press. 1976; p.326.

CNCflora (Centro Nacional de Conservação da Flora). Open in http://cncflora.jbrj.gov.br/portal. acess in 07 de outubro, 2017.

CUTLER DF, BOTHA T, STEVENSON DWM. Anatomia Vegetal - Uma abordagem aplicada. São Paulo, ArtMed Editora. 2011; p.304.

DASILVA MB. Areas of endemism: do species live anywhere, where they can, or where they historically evolved and speciated? Revista da Biologia vol. Esp. Biogeografa. 2011; 12-17.

ELIAS SR, ASSIS RM, STACCIARINI-SERAPHIN E, REZENDE MH. Leaf anatomy in young plants of Solanum lycocarpum A. St.-Hil. (Solanaceae). Brazilian Journal of Botany. 2003; 26: 169-174.

FAHN A, CUTLER D. Xerophytes. Gebrüder Borntraeger, Berlin. 1992; p.176.

FANK-DE-CARVALHO SM, BÁO SN. Contribuições ao conhecimento da anatomia, micromorfologia e ultraestrutura foliar de Amaranthaceae do Cerrado. 2011. Instituto de 
Biologia. Doutorado em Biologia Celular e Estrutural, Universidade Estadual de Campinas, Campinas, SP, Brazil. (Thesis) 107p.

FANK-DE-CARVALHO SM, GOMES MRDA, SILVA PÍT, BÁO SN. Leaf surfaces of Gomphrena spp. (Amaranthaceae) from Cerrado biome. Biocell. 2010b; 34(1): 23-35.

FANK-DE-CARVALHO SM, MARCHIORETTO MS, BÁO SN. Leaf anatomy, morphology and ecological aspects of Amaranthaceae species from Reserva Particular do Patrimônio Natural Cara Preta, in Alto Paraíso, GO, Brazil. Biota Neotropica. 2010a; 10(4):77-86.

FANK-DE-CARVALHO SM, BÁO SN, MARCHIORETTO MS. Amaranthaceae as a bioindicator of neotropical savannah diversity. In Biodiversity Enrichment in a Diverse World. 2012; InTech: 235-256.

FANK-DE-CARVALHO SM, SOMAVILLA NS, MARCHIORETTO MS, BÁO SN. Plant structure in the Brazilian neotropical savannah species. In: Biodiversity in Ecosystems-Linking Structure and Function. 2015; InTech: 425-460.

FERNANDES VF, BEZERRA LDA, MIELKE MS, SILVA DDC, COSTA LCDB. Leaf anatomy and ultrastructure of Ocimum gratissimum under different light radiation levels. Ciência Rural. 2014; 44(6): 1037-1042.

FRANCESCHI V, HORNER JR. HT. Calcium oxalate crystals in plants. The Botanical Review. 1980; 46: 361-427. California.

FRANKLIN GL. Preparation of thin sections of synthetic resins and wood-resin composites, and a new macerating method for wood. Nature. 1945; 155(3924): 51.

FREITAS EM, BOLDRINI II, MÜLLER SC, VERDUM R. Floristics and phytosociology of grassland vegetation subject to sandy desertification in southwestern Rio Grande do Sul State, Brazil. Acta Botanica Brasilica. 2009; 23(2): 414-426.

FREITAS EM, TREVISAN R, SCHNEIDER ÂA, BOLDRINI II. Floristic diversity in areas of sandy soil grasslands in Southwestern Rio Grande do Sul, Brazil. Revista Brasileira de Biociências. 2010; 8(1): 112-130.

GARNER DMG, MURE CM, YERRAMSETTY P, BERRY JO. Kranz anatomy and the C4 pathway. In: eLS Wiley \& Sons, Ltd: Chichester. 2016.

GIULIETTI AM, DE QUEIROZ LP, WANDERLEY MDGL, VAN DEN BERG C. Biodiversity and plant conservation in Brazil. Megadiversidade. 2005; 1(1): 52-61.

GRIGORE MN, TOMA C. Histo-anatomical strategies of Chenopodiaceae halophytes: adaptive, ecological and evolutionary implications. WSEAS Transactions on Biology and Biomedicine. 2007; 4(12): 204-218. 
JÁUREGUI D, CASTRO M, RUIZ-ZAPATA T, LAPP M. Anatomy of the vegetative organs of two species of Atriplex (Chenopodiaceae) from Venezuela. Revista de Biologia Tropical. 2014; 62(4): 1625-1636.

JOHANSEN DA. Plant microtechnique. New York: Mcgraw-Hill Book. 1940;p.523.

JOHNSON H B. Plant pubescence: an ecological perspective. The Botanical Review. 1975; 41(3): 233-258.

KRAUS JE, ARDUIM M. Basic method manual in plant morphology. EDUR. 1997; p.198. Rio de Janeiro.

MARCHIORETTO MS, DE AZEVEDO F, JOSENDE MVF, SCHNORR DM. Biogeography of the Amaranthaceae family in Rio Grande do Sul. Pesquisas, Botânica. 2008; 59: 171-190.

MARCHIORETTO MS, WINDISCH PG, DE SIQUEIRA JC. Geographical distribution patterns of the species of Froelichia Moench and Froelichiella R. E. Fries (Amaranthaceae) in Brazil. Iheringia Série Botânica. 2004; 59(2): 149-160.

MARCHIORETTO MS, WINDISCH PG, SIQUEIRA JC. Problems of conservation of the species of the genera Froelichia Moench and Froelichiella R.E. Fries (Amaranthaceae) in Brazil. Acta Botanica Brasilica. 2005; 19(2): 215-219.

MARCHIORETTO MS. Species of the Pampa Biome: Amaranthacae. $64^{\circ}$ Congresso Nacional de Botânica. 2013.

MARTINS S, MACHADO SR, ALVES M. Anatomia e ultra-estrutura foliar de Cyperus maritimus Poir. (Cyperaceae): estratégias adaptativas ao ambiente de dunas litorâneas. Acta Botanica Brasilica. 2008; 22: 493-503.

METCALFE CR, CHALK L. Anatomy of the Dicotyledons. At The Clarendon Press; Oxford. 1950.

METZGER JP, BUSTAMANTE MMC, FERREIRA J, FERNANDES GW, LIBRÁN-EMBID F, PILLAR VD, PRIST PR, RODRIGUES RR, VIEIRA ICG, OVERBECK GE. Why Brazil needs its Legal Reserves. Perspectives in Ecology and Conservation. 2019; 17(3): 104-116.

MMA - MINISTÉRIO DO MEIO AMBIENTE. Áreas prioritárias para a conservação, uso sustentável e repartição de benefícios da biodiversidade brasileira: atualização - Portaria MMA nº 09, de 23 de janeiro de 2007. Ministério do Meio Ambiente - Secretaria de Biodiversidade e Florestas, Brasília, 2007; p. 300.

MOTT KA, GIBSON AC, O'LEARY JW. The adaptative significance of amphistomatic leaves. Plant, Cell and Enviroment. 1982; 5: 455-460.

MUHAIDAT R, SAGE RF, DENGLER NG. Diversity of Kranz anatomy and biochemistry in C4 eudicots. American Journal of Botany. 2007; 94(3): 362-381. 
NIMER E. 1979. Climatologia do Brasil. IBGE - Superintendência de Recursos Naturais e Meio Ambiente. 1979; p. 422. Rio de Janeiro.

OLIVEIRA MG, SUERTEGARAY DMA. Processos Geomorfológicos na Evolução da Paisagem/Geomorphological Processes in Landscape Evolution. Revista FSA (Faculdade Santo Agostinho). 2014;11(2): 211-233.

OVERBECK GE, MÜLLER SC, FIDELIS A, PFADENHAUER J, PILLAR VDP, BLANCO CC, BOLDRINI II, BOTH R, FORNECK ED. Os Campos Sulinos: um bioma negligenciado. Em: Pillar VDP, Müller SC, Castilhos ZMC, Jacques AVA. (eds.). Campos Sulinos - conservação e uso sustentável da biodiversidade. MMA. 2009; 26-41. Brasília.

PALMA JM, CORPAS FJ, DEL RÍO LA. Proteome of plant peroxisomes: new perspectives on the role of these organelles in cell biology. Proteomics. 2009; 9(9): 2301-2312.

PILLAR VDP, LANGE O. Os Campos do Sul. Rede Campos Sulinos-UFRGS. 2015; p.192.

PLAYUK JÁ. Estudios morfo-anatómicos de Gomphrena perennis, maleza tolerante al glifosato. Doctoral dissertation, Facultad de Ciencias Agrarias y Forestales. 2016

PURVIS M, COLLIER D, WALL D. Laboratory Techniques in Botany. London, Butterworths. 1964.

SAGE RF, SAGE TL, PEARCY RW, BORSCH T. The taxonomic distribution of C4 photosynthesis in Amaranthaceae sensu stricto. American Journal of Botany. 2007; 94(12): 1992-2003.

SASS J. Botanical microtechnique. The lowa State College Press, Ames. 1951;p.228.

SCOPEL I, SOUSA MS, PEIXINHO DM, MARTINS AP. Survey of areas under arenization and land use in southwest of Goiás state and in the southwest of Rio Grande do Sul state - Brazil. Revista Eletrônica de Geografia. 2013; 5(15): 24-47.

SEMA. 2013. Secretaria do Meio Ambiente, Portaria SEMA n 79 de 31 de outubro de 2013.http://www.institutohorus.org.br/download/marcos_legais/Portaria\%20SEMA\%20RS\%20 79\%20\%202013\%20Lista\%20invasoras. PDF. Accessed in December 2017.

SILVA LDB, MEDEIROS JD. Anatomia foliar comparativa de Psidium cattleyanum Sab. (Myrtaceae). Insula Botânica. 2005; 34: 15-38.

SIMIONI PF, EISENLOHR P V, PESSOA MJG, SILVA IV. Elucidating adaptive strategies from leaf anatomy: Do Amazonian savannas present xeromorphic characteristics?. Flora. 2017; 226: 3846.

SIQUEIRA JC. Amaranthaceae. Wanderley MGL, Shepherd GJ, Giulietti AN, Melhem TSA, Dittrich V, Kameyama C. Flora fanerogâmica do Estado de São Paulo. 2002; 2: 11-30. 
SOMAVILLA NS, GRACIANO-RIBEIRO D. Análise comparativa da anatomia foliar de Melastomataceae em ambiente de vereda e cerrado sensu stricto. Acta Botanica Brasilica. 2011; 25(4): 764-775.

STRECK EV, KÄMPF N, DALMOLIN RSD, KLAMT E, NASCIMENTO PC, SCHNEIDER P, GIASSON E, PINTO LFS. Solos do Rio Grande do Sul. $2^{\text {a }}$ ed. Porto Alegre: EMATER/RS. 2008; p. 222.

SUERTEGARAY DMA, BERTE AMA. 1997. Forestry Policies in Degraded Areas: Sands of the Southwest of Rio Grande do Sul. Geosul Revista do Departamento de Geociências CFH, Editora da UFSC. 1997; 26: 56-70.

SUERTEGARAY DMA, GUASSELI LA, VERDUM R, BASSO LA, MEDEIROS RMV, BELLANCA ET, DE AVELINE BERTÊ AM. Sandstone project in Rio Grande do Sul, Brazil: genesis, dynamics and spatialization. Revista Bibliográfica de Geografia y Ciencias Sociales. 2001; 287: 349-356.

VOZNESENSKAYA EV, FRANCESCHI VR, PYANKOV VI, EDWARDS GE. Anatomy, chloroplast structure and compartmentation of enzymes relative to photosynthetic mechanisms in leaves and cotyledons of species in the tribe Salsoleae (Chenopodiaceae) Journal of Experimental Botany. 1999; 50: 1779-1795. 


\section{Authorship Contribution}

\section{1 - Aline Viana}

Pós-graduação em Biotecnologia

alineee_viana@hotmail.com - https://orcid.org/0000-0001-5931-4512

Contribution: Conceptualization, Investigation, Methodology, Validation, Visualization, Writing - original draft, Writing - review \& editing

\section{2 - Elisete Maria de Freitas}

Doutora em Botânica

elicauf@univates.br - http://orcid.org/0000-0002-9292-1557

Contribution: Conceptualization, Investigation, Project administration, Writing original draft, Writing - review \& editing

\section{3 - Shirley Martins}

Doutora em Ciências Biológicas

shirley_botany@yahoo.com.br - https://orcid.org/0000-0002-7696-8865

Contribution: Conceptualization, Supervision, Resources, Project administration; Writing - original draft, Writing - review \& editing

\section{How to quote this article}

VIANA, A.; FREITAS, E. M.; MARTINS, S. Morphology, anatomy and ultrastructure of the leaf blade in Froelichia tomentosa (Mart.) Moq. (Amaranthaceae A. Juss): - a critically endangered species in Brazil. Ciência e Natura, Santa Maria, v. 43, e26, p. 1-19, 2021. DOI 10.5902/2179460X40503. Available from: https://doi.org/10.5902/2179460X40503. Accessed: Month Abbreviated. day, year. 